\title{
The Role of Family in Dealing with Juvenile Delinquency
}

\author{
Rosemary Kakonzi Mwangangi \\ Juvenile Justice, University of Geneva, Geneva, Switzerland \\ Email: mkrosem@gmail.com
}

How to cite this paper: Mwangangi, R.K. (2019) The Role of Family in Dealing with Juvenile Delinquency. Open Journal of Social Sciences, 7, 52-63.

https://doi.org/10.4236/jss.2019.73004

Received: January 17, 2019

Accepted: March 5, 2019

Published: March 8, 2019

Copyright $\odot 2019$ by author(s) and Scientific Research Publishing Inc. This work is licensed under the Creative Commons Attribution International License (CC BY 4.0).

http://creativecommons.org/licenses/by/4.0/

\begin{abstract}
The overall purpose of the study was to explore the relationship between various family-related factors and crime. The study also attempted to ascertain whether those factors can act as causative agents for "juvenile delinquency". The study postulated that although there are different factors that impact on the development of child character, the family plays a central role in child development and consequentially impacting on the character of a child. In order to critically analyze the hypothesis of study, the paper reviewed the concepts of juvenile delinquency and family. Although the paper centered on the family factors influencing delinquency, it equally attached premium on the non-family factors influencing levels of juvenile delinquency. The study found out that there are several notable family-related factors that impact on child crime. These include parental attitudes, the degree of family cohesion, physical violence, and uninvolved parenting. There are also non-family factors that impact on juvenile delinquency, which include the failure of the juvenile justice system, poverty, a lack of access to education, drug abuse and genetic problems.
\end{abstract}

\section{Keywords}

Juvenile Delinquency, Family, Family Structures, Character Change, Child Development, Social Cohesiveness, Emotional Skills, Marriage, Criminal Acts, Antisocial Behaviour

\section{Introduction}

The family has been seen to be a critical element for child development and as a determining factor for children's subsequent involvement in crime. This paper seeks to explore the relationship between various family-related factors and crime. It also attempts to ascertain whether these factors can act as causative agents for 
"juvenile delinquency" or whether this is caused by the interaction between the family and other external factors.

\section{The Concepts of Family; Child Development; and Juvenile Delinquency}

\subsection{The Concept of Family}

The concept of family has received a variety of definitions, because families vary greatly in their sizes and constituent parts. These various types of family accomplish different things for their family members [1]. The Population Reference Bureau defines a family as a group of people held together by common birth, marriage, residence, close emotional attachment or adoption [2], while for Desai a family means a unit of two or more persons united by blood, marriage, adoption or consensual union who interact and communicate with each other. Families may also include people with common ancestors, as part of a lineage, clan or tribe. UNESCO broadly defines a family as being a social reality, although the kinship unit and members do not have to share a common household [3].

Although there are a number of differences in the types of families found in the world, they have certain things in common. For example, families serve several important functions within society, including socialization, economic support, nurturing, protection of vulnerable members, and perpetuating the family grouping [4]. In general, despite differences between cultures, families serve the three basic goals of economic self-sufficiency, improving family circumstances and perpetuating their existence.

The traditional concept of family includes responsibilities and functions such as intimacy and affection, security, childbearing and child-rearing [5]. Traditional family tasks include assigning roles, assuring social interaction between family members, providing physical care, allocating resources, maintaining morale and motivation and relating to external society and its institutions.

Increasing rates of divorce and remarriage have led to the emergence of reconstituted families (stepfamilies), which represent households containing a child or children who are biologically related to only one of the adults. Changes in the social environment often require adaptations in family structure and functioning.

\subsection{Concept of Child Development}

The term "child development" denotes the healthy growth of a child, including emotional, intellectual, perceptual and behavioral capabilities. It is also a term referring to the scientific study of the patterns of change, growth and stability that occur from conception through to adolescence. The stages of development include the "prenatal period" from conception to birth, the "infancy period" from birth up to 2 years, "early childhood" from 2 until 6 years old, "middle childhood" from 6 to 12 years old, and "adolescence" from 12 to 19 years old. 


\subsection{Concept of Child Character Determination}

According to John Watson, who is credited as being the father of American Behaviorist Theory, children are passive beings who can be molded by controlling stimulus-response associations, while the U.S. Department of Education believes that children can be taught to become responsible human beings. "Responsibility" has been defined by Mitton and Harris as being the capacity to make choices and to accept the consequences of those choices, so positive child development should aim to teach children to accept full responsibility for their actions [6]. For the process of acquiring responsibility to be effective, children must understand the values they are being taught and must habitually apply these values to their lives. This underscores the importance of parental instruction, as children need guidance from their parents to help them succeed in tasks. According to Whitebread and Wingham, habitual success in tasks makes children successful in life. Conversely, unsuitable home conditions and an unstable family can lead to negative attitudes and habitual failure in tasks, which in turn encourages children to become delinquents.

\subsection{Concept of Child Character Determination}

The concept of "juvenile delinquency" can be understood from different theoretical standpoints [7]. While sociologists believe that "juvenile delinquency" encompasses a variety of violations of legal and social norms, ranging from minor to serious offenses [8] criminologists view "juvenile delinquency" as entailing all the public wrongs committed by those between the ages of 12 and 20.

Sociologists assert that antisocial behavior may be the expression of either the beginning of a long term culture of criminal activity or a normal part of the process of growing up [9].

The United Nations Guidelines for the Prevention of Juvenile Delinquency do not classify anti-social conduct or youthful behavior as "juvenile delinquency" or conduct that could lead to future criminal tendencies. Instead, these guidelines are clear that such behavior is often part of the process of growth and maturation and tends to disappear spontaneously in most individuals during the transition to adulthood. The United Nations note that there is a common tendency for young people to commit some kind of petty offence at some point during their adolescence, without them subsequently turning into career criminals. Similarly, the World Youth Report of 2003 recognizes that child delinquency is a common phenomenon during the transition from childhood to adulthood.

The UN found that juvenile delinquency is largely a group phenomenon, as between two thirds and three quarters of all juvenile offences were found to have been committed by young people who belonged to groups such as gangs. In the Russian Federation, criminal activity among juveniles in groups was found to be higher than that of adult offenders. This tendency for juveniles to indulge in criminal activity while belonging to groups can be traced to the fact that juvenile peer groups have certain unique characteristics, such as hierarchical organiza- 
tion, high levels of social cohesiveness, and a code of behavior that is based upon a common rejection of the values and experiences of adults [10]. Delinquent or criminal behavior is caused by certain groups and juvenile subcultures (subcultures of violence) that tend to use violence and aggression as an acceptable and even preferable means of solving interpersonal conflicts.

\section{The Roles of the Family in Controlling Juvenile Delinquency through Enhancing Child Development}

Uwo et al. believe that the proper nurturing of children is the primary responsibility of parents, because the values given to children and the type of training they receive from their parents seem to largely determine their future life-style. Parents help their children establish certain behavioral attitudes, and once established these attitudes are difficult to change or suppress. Parents who instill antisocial attitudes and behaviors in their children encourage such attitudes to persist into adulthood [11].

Child development has emotional, intellectual, social and physical aspects, with the family being the foundation upon which this development occurs. The family structure plays an important role in shaping a child by providing security and developing their, values and skills.

\subsection{Development of the Security of a Child}

Children rely on the family for their basic needs, such as clothing, shelter and food, with their family providing their primary sense of physical security [12]. They also get emotional security from the family that can find nowhere else, allowing children to grow in confidence and be able to express themselves fully. Giving children a stable home routine also enables them to feel secure, as they know they will eat, drink, bathe, and sleep at certain times without being disturbed [13]. The different committee have also been established such as; Committee on the Rights of the Child, Human Rights Committee, Committee against Torture, Human Rights Commissioner, their advocacy is a sign of security if followed and implemented which is not always the case.

Security for children is a recipe for them to develop their skills and talents, grow physically, and develop cognitively and emotionally. Security is also important in building trust between children and family members. When children know that they can trust those around them, they feel more comfortable and secure.

\subsection{Development of a Child's Values}

The family plays an important role in inculcating norms and values within children [14]. These include an understanding of right and wrong, respect, fairness, compassion and responsibility [15]. Children learn these values by observing and emulating their parents' behavior, and being taught by their parents. Thus, children learn both the importance of these values and the consequences of not observing them. 


\subsection{Development of a Child's Skills}

The moment children are born, they start learning skills that include cognitive, emotional, interactional and language skills [16]. These skills are acquired over time and are very important as they shape a person and improve their ability to fulfill their potential. For example, emotional skills are important for children as they teach them how to deal with life's difficulties and when to have sympathy and compassion for others. Without emotional skills, children are inclined to engage in destructive choices when they are older. For example, children with low emotional skills are likely to engage in criminal activities [17].

\section{The Impact of Different Family Structures (Married, Cohabiting and Divorced Families) on Determining Child Delinquency}

\subsection{Married Families}

According to Wardle, children need a stable marriage between their mother and father to be able to enjoy the best preparation and opportunities for life success and happiness [18]. Marriage has a strong, positive and consistent effect on the wellbeing of children, and appears to play an important role in contributing to their happiness, health and security and thus to accord them optimal life opportunities [19]. Hafen views the positive effect of marriage as being the most important causal factor in determining the well-being of children.

Children with married parents are better placed to avoid some of the "growing up disasters" associated with adolescence and childhood. For example, it has been found that children who are brought up in single-parent households are at a higher risk of experiencing educational and behavioral problems, such as a tendency to engage in criminal acts. Specifically, it has been noted that the separation of children from their fathers is a major cause of many social problems, including adolescent pregnancy, crime, child sexual abuse and domestic violence. The National Report on Juvenile Offenders and Victims provided by The Office of Juvenile Justice and Delinquency Prevention of the U.S Justice Department found that juveniles who lived with both parents were less likely to be engaged in delinquent acts, including sexual violence and drug abuse. The Report found that only $5 \%$ of youths who lived with both parents engaged in delinquent acts, as opposed to $12 \%$ of youths who lived in other family arrangements. A similar report in 2010 found that $45 \%$ of youths who were in custody for delinquent acts were from single-parent families, while 30\% were from two-parent families.

Raising children with both parents has thus proved to be beneficial in developing emotional health and increasing the likelihood of academic success including college attendance. Consequently, the remarkable increases in divorce and family break-ups since the 1970's has led to significant family instability and decreasing parental investment in children. This has had an adverse impact on the character development of children and increased the likelihood of their in- 
volvement in delinquent acts.

\subsection{Divorced Families}

Parental divorce has been cited as a consistent predictor of juvenile delinquency and a major parent-related risk factor for criminal development in childhood and adolescence, [20] leading to increased criminal convictions and antisocial behavior. Disciplinary and behavioral issues have been studied from many theoretical perspectives, including the emotional distress that derives from parental divorce. It appears that children from one-parent families are more likely to be unemployed, drop out of school, have lower psychological well-being and engage in sexual violence than children from two-parent families [21]. The transition from a two-parent to a single-parent family often results in the loss of economic resources, because there is only one bread-winner in the family, and causes a decrease in child supervision [22]. Fathers who live in separate households also tend to have less contact with their children, thus undermining commitment and trust.

According to Amato, post-divorce negative outcomes, such as the transfer of children to other schools, can lead to economic hardship, as well as causing the disruption of family structures [23]. Such disruptions have been found to increase poverty and depression, and cause ineffective parenting strategies that in turn lead to high rates of criminal behavior. The correlation between divorce and delinquency has been disputed by Capaldi and Patterson, however, who believe that delinquency can be due to some mothers having antisocial personalities [24].

\subsection{Cohabiting Families}

A study of 74 child offenders by Sarantakos has shown that $74 \%$ come from families with cohabiting partners, while only $26 \%$ are from those with married couples [25]. Moreover, while $49 \%$ of the children from families with cohabiting couples committed two or more offences, just $21 \%$ of those from married couples committed two or more offences, and only the children from cohabiting couples committed three or more offences. These findings are clearly linked to the family environments of most offenders, which are characterized by low integration, instability, domestic violence, hostile parental attitudes, parental indifference and parental conflicts. The study did not find a causal relationship between delinquency and cohabitation as a lifestyle.

\section{Family Factors Influencing Levels of Juvenile Delinquency}

\subsection{Parental Attitudes}

For children, family is the major source of companionship, affection and reassurance. The nature of the relationship between parents and their children helps to determine whether a child becomes a delinquent. Affectionate, supportive, and understanding homes are likely to promote conformist and constructive so- 
cial behavior, because a positive family environment leads to healthy personality development. Conversely, a lack of parental affection and support, or in more severe cases parental indifference, hostility or rejection, causes children to feel emotionally insecure and leads to poor personality development, thus encouraging antisocial or delinquent behavior. Negative parental attitudes often include scolding and a lack of love [26].

Another negative attitude is that of authoritarian parenting, where excessive control, using harsh and strict commands, deprives children of the freedom to express themselves. The suppression of free expression and an absence of love encourage children to revolt against their parents, to run away from their families, and consequently to enter a life of crime.

Negative parental attitudes, including concealing information or failing to respond to questions, have been shown to induce feelings of emotional and social insecurity in children. Such insecurity can degenerate into children developing mental problems, or can lead to delinquent behavior.

\subsection{Level of Family Cohesion}

Shields and Clark have noted that low levels of family cohesion are likely to lead to juvenile crime [27]. Similarly, Sarantakos found that $73 \%$ of juvenile offenders came from families with low cohesion, while just $27 \%$ of offenders came from families with high cohesion. He also found that while $91 \%$ of non-offenders came from high-cohesion families, only $9 \%$ of non-offenders came from low-cohesion families.

\subsection{Level of Violence}

The level of violence between parents and towards their children can also influence levels of juvenile delinquency. Sarantakos found that $78 \%$ of child offenders came from families that experienced physical violence and child abuse, while only $22 \%$ of child offenders came from non-violent homes. Non-offenders are much more likely to come from non-violent homes than from those that are subject to physical or emotional violence.

\subsection{Uninvolved Parenting}

According to Hearne, "uninvolved parenting" describes situations where parents are emotionally distant from their children and show little warmth and love towards them, provide little supervision, intentionally avoid them, have few expectations or demands for their behavior, never attend school events, and are generally too overwhelmed by their own problems to deal with their children [28]. Sarantakos argues that juvenile offenders are more likely to come from families with uninvolved parenting than from those with interested parents. He found that approximately two thirds of offenders came from families in which the children perceived their parents to show no interest in them, while only one third of offenders came from families with parents who were interested in them. 
Similarly, $86 \%$ of non-offenders came from families with parents who were "interested" in their children.

\section{Non Family Factors Influencing Levels of Juvenile Delinquency}

\subsection{Poverty}

Birckhead has shown that an inability to afford certain basic commodities such as food and clothing, has significantly contributed to juvenile delinquency [29]. Areas with high rates of poverty have correspondingly high rates of juvenile delinquency. Registered juvenile delinquents are concentrated in urban areas that coincide with low poverty indices, while they are thinly scattered in better residential areas. High concentrations of juvenile delinquents can thus be found in the slums of large cities, associated with extreme levels of poverty, bad housing, overcrowding and a severe lack of recreational facilities.

\subsection{Lack of Access to Education}

Lack of access to education is also a major contributor to juvenile delinquency [30]. Factors preventing children gaining access to education include the costs of schooling, distance from schools, abusive or absent teachers, and poor quality teaching. A lack of education may result in desperation and idleness among children, encouraging them to engage in delinquent activities.

\subsection{Drug Abuse}

Drug abuse has been found to be a major contributor to juvenile delinquency, as drugs have a number of highly negative impacts on children. For example, children who persistently abuse drugs tend to experience learning difficulties, poor peer and family relationships and health problems [31]. Drug abuse can also cause compulsive economic behavior, a condition in which some drug users resort to violence as a way of supporting their addiction [32]. Drugs can also reduce cognitive ability, thus exposing users to episodes of miscommunication and limiting their capacity for compromise and for rational dialogue.

\subsection{Delinquency Caused by Genetic Factors}

Some children are born with antisocial personality disorder, a condition that is associated with abnormal/destructive thinking, perception and relationships with others [33]. This condition is closely linked with delinquent behavior, as persons suffering from this condition have no regard for right and wrong, and often engage in drug abuse and violence, leading to them being reprimanded as juvenile delinquents [34].

\section{Conclusion}

This paper sought to assess the role of the family in contributing to juvenile delinquency. After examining the two concepts of family; child development; and 
juvenile delinquency, the paper concludes that the family has an important role in determining whether a child might engage in delinquency or antisocial acts. Owing to the centrality of families in children's lives, they play a crucial role in developing children's values, skills and sense of self. The development of children thus greatly influences their future character and the likelihood of them engaging in delinquent acts. Last and not least, it is very important to encourage the formation of parents and to promote public policies that support the family as a qualitative space for communication and affective relationships, with all that, there is urgent need of relevant strategies on child protection with specific focus on preventing child abuse, negligence among others which in some cases has extended to gang recruitment and access to small arms, hence juvenile delinquency.

\section{Recommendations}

On the basis of the finding that the family plays a central role in determining the levels of juvenile delinquency, this study makes the following recommendations:

1) There is need for an emphasis on the importance of stable family structures as a means of offering children secure households in which they can be taught and absorb constructive social values. This will help in reducing the rate of child delinquency.

2) Governments ought to reconsider their economic policies in order to mitigate poverty levels in families. Specifically, governments should consider making provisions for free educational opportunities, counseling, and mentoring programs for children.

3) The juvenile justice system ought to be remodeled to take into account the numerous factors that cause juvenile crime, and consequently offer viable and all-inclusive solutions. In specific terms, the juvenile justice systems should be structured to address child crimes from a solution's perspective but not treat the same from a linear approach of offenses and penalties.

4) There is need for multi-sectorial engagement in offering solutions to juvenile crime. Sectors including the community, schools, the religious communities and government authorities need to engage combined efforts to address juvenile crime. This is in contradistinction to the contemporary approach of reserving juvenile offenses to the justice system.

\section{Conflicts of Interest}

The author declares no conflicts of interest regarding the publication of this paper.

\section{References}

[1] Gordon, L. (2003) Families: Basic Concepts.

[2] Enrique, J., Howk, H. and Huitt, W. (2007) An Overview of Family Development. Educational Psychology Interactive. Valdosta State University, Valdosta, GA. http://www.edpsycinteractive.org/papers/family.pdf 
[3] UNESCO (1992) The Changing Family in Asia: Bangladesh, India, Japan, Philippines and Thailand.

[4] Patterson, J.M. (2002) Understanding Family Resilience. Journal of Clinical Psychology, 58, 233-246. https://onlinelibrary.wiley.com/doi/full/10.1002/jclp.10019 https://doi.org/10.1002/jclp.10019

[5] Suzanne, K. and Karen, F.S. (1998) Traditional and Emerging Families: A Typologr Based on Structures and Functions. Family Science Review.

http://www.familyscienceassociation.org/sites/default/files/Vol\%201\%20No\%202\%2 0Article\%202.PDF

[6] Mitton, B.L. and Harris, D.B. (1954) The Development of Responsibility in Children. The Elementary School Journal, 54, 268-277.

http://www.jstor.org/stable/998563 https://doi.org/10.1086/458585

[7] World Youth Report Juvenile Delinquency (2003) http://www.un.org/esa/socdev/unyin/documents/ch07.pdf

[8] Zembrosk, D. (2011) Sociological Theories of Crime. https://pdfs.semanticscholar.org/5f27/920a8cc1103a950d33e95b64b1a09e98dee0.pdf

[9] Petrosino, A., Derzon, J. and Lavenberg, J. (2011) The Role of the Family in Crime and Delinquency: Evidence from Prior Quantitative Reviews. https://pdfs.semanticscholar.org/2623/77e9c296f552b7c958c280620a52fa3bdb60.pdf

[10] Felson, R.B., et al. (1994) The Subculture of Violence and Delinquency: Individual vs. School Context Effects. Social Forces, 73, 155-173.

http://www.jstor.org/stable/2579921 https://doi.org/10.1093/sf/73.1.155

[11] Chaffin, M., et al. (2004) Parent-Child Interaction Therapy with Physically Abusive Parents: Efficacy for Reducing Future Abuse Reports. Journal of Consulting and Clinical Psychology, 72, 500-510.

https://pdfs.semanticscholar.org/bac7/a9089a9001c4da90d7222369faf6d7494697.pdf https://doi.org/10.1037/0022-006X.72.3.500

[12] Gennetian, L.A., Nina, C. and Pamela, M. (2010) Meeting the Basic Needs of Children: Does Income Matter? Children and Youth Services Review. https://www.ncbi.nlm.nih.gov/pmc/articles/PMC2913899/pdf/nihms194604.pdf

[13] de Mello, D.F., et al. (2014) Child Safety from the Perspective of Essential Needs. Rev. Latino-Am. Enfermagem, 22. https://doi.org/10.1590/0104-1169.3651.2458 http://www.scielo.br/pdf/rlae/v22n4/0104-1169-rlae-22-04-00604.pdf

[14] Mwenda, N. (2012) Introduction: Parents' Involvement in Children's Lives in Africa. Africa Development/ Afrique Et Dévelopment, 37, 1-18.

http://www.jstor.org/stable/afrdevafrdev.37.3.1

[15] Mary, J.B. (2016) Role of Parents in Inculcating Values. JARIIE http://ijariie.com/AdminUploadPdf/ROLE_OF_PARENTS_IN_INCULCATING_V ALUES_c1264.pdf

[16] Kalb, G. and Jan, C. (2013) Ours Reading to Young Children: A Head-Start in Life? https://poseidon01.ssrn.com/delivery.php?ID $=8061011240290261130910010080780$ 3007705800801908404400110900411700711306807207010207500912205403112212 0108118006095069101098013008085046038081099119084071120122124075091060 0730851130860070640120850980170920830740010290760680750880640881240770 $31084125003 \& \mathrm{EXT}=\mathrm{pdf}$

[17] Kruttschnitt, C., et al. (1987) Abuse-Resistant Youth: Some Factors That May Inhibit Violent Criminal Behavior. Social Forces, 66, 501-519. 
http://www.jstor.org/stable/2578752

https://doi.org/10.1093/sf/66.2.501

[18] Wardle, L.D. (2004) Children and the Future of Marriage. Regent University Law Review, 17, 279-310.

https://www.regent.edu/acad/schlaw/student_life/studentorgs/lawreview/docs/issue s/v17n2/Wardle.pdf

[19] Waite, L.J. (1995) Does Marriage Matter? Demography, 483, 497-498. https://doi.org/10.2307/2061670

[20] Burt, S.A., et al. (2008) Parental Divorce and Adolescent Delinquency: Ruling out the Impact of Common Genes. Developmental Psychology, 44, 1668-1677.

https://www.ncbi.nlm.nih.gov/pmc/articles/PMC2593091

https://doi.org/10.1037/a0013477

[21] Van de Weijer, S.G.A., et al. (2015) The Effects of Parental Divorce on the Intergenerational Transmission of Crime. Societies, 5, 89-108.

https://www.google.com/url?sa=t\&rct=j\&q=\&esrc=s\&source=web\&cd=3\&cad=rja\& uact=8\&ved=2ahUKEwj_6cih8pndAhUOTBoKHSg6DAAQFjACegQIBxAC\&url=h ttp\%3A\%2F\%2Fwww.mdpi.com\%2F2075-4698\%2F5\%2F1\%2F89\%2Fpdf\&usg=AO vVaw08biczazJOayjnjkPtr06v https://doi.org/10.3390/soc5010089

[22] McLanahan, S. and Sandefur, G. (1994) Growing up with a Single Parent: What Hurts, What Helps. Harvard University Press, Cambridge.

[23] Amato, P.R. (2000) The Consequences of Divorce for Adults and Children. Journal of Marriage and Family, 62, 1269-1287. https://doi.org/10.1111/j.1741-3737.2000.01269.x

[24] Capaldi, D.M. and Patterson, G.R. (1991) Relation of Parental Transitions to Boy's Adjustment Problems: I. A Linear Hypothesis. II. Mothers at Risk for Transitions and Unskilled Parenting. Developmental Psychology, 27, 489-504. https://doi.org/10.1037/0012-1649.27.3.489

[25] Sarantakos, S. (1997) Cohabitation, Marriage and Delinquency: The Significance of Family Environment. The Australian and New Zealand Journal of Criminology, 30, 187-199. https://doi.org/10.1177/000486589703000205

http://citeseerx.ist.psu.edu/viewdoc/download?doi=10.1.1.907.4399\&rep=rep1\&type $=\mathrm{pdf}$

[26] Akinyi, O.D. (2015) Effects of Authoritarian Parenting Model on Learner Participation in Early Childhood Education Science Class Kabondo Division, Homabay County, Kenya.

http://erepository.uonbi.ac.ke/bitstream/handle/11295/95154/Onyango\%2C\%20Da ugh-

ty\%20A_Effects\%20of\%20authoritarian\%20parenting\%20model\%20on\%20learner \%20participation\%20in\%20early\%20childhood\%20education $\% 20$ science $\% 20$ class $\%$ 20Kabondo\%20division $\% 2 \mathrm{C} \% 20$ Homabay $\% 20$ county $\% 2 \mathrm{C} \% 20$ Kenya..pdf?sequence $=1$ \&isAllowed $=\mathrm{y}$

[27] Shields, G. and Clark, R.D. (1995) Family Correlates of Delinquency: Cohesion and Adaptability. The Journal of Sociology \& Social Welfare, 22, 93-106.

https://scholarworks.wmich.edu/cgi/viewcontent.cgi?referer=https://www.google.co $\mathrm{m} /$ \&httpsredir $=1$ \&article $=2243$ \&context $=$ jssw

[28] Hearne, B.N. (2015) The Effect of Parenting Styles and Depressive Symptoms on Young Adult's Educational Attainment.

https://etd.library.vanderbilt.edu/available/etd-03112015-132337/unrestricted/Hear 
ne.pdf

[29] Birckhead, T.R. (2012) Delinquent by Reason of Poverty. Washington University Journal of Law and Policy, 38, UNC Legal Studies Research Paper No. 1918331.

http://ssrn.com/abstract $=1918331$

[30] Nanjala, S.L. (2008) Analysis of the Factors Leading to Juvenile Delinquency: The Case of Murang'a Children's Remand Home.

http://erepository.uonbi.ac.ke/bitstream/handle/11295/6346/Nanjala_Analysis\%20 Of\%20The\%20Factors\%20Leading\%20To\%20Juvenile\%20Delinquency\%20The\%20 Case\%20Of\%20Murang\%E2\%80\%99A\%20Children\%E2\%80\%99S\%20Remand\%20 Home..pdf?sequence $=1$ \&isAllowed $=\mathrm{y}$

[31] Petersen, A.C., Joseph, J. and Feit, M. (2018) New Directions in Child Abuse and Neglect Research. https://www.ncbi.nlm.nih.gov/books/NBK195987

[32] Powell, M.A. (2011) A Comprehensive Analysis of the Drug-Crime Relationship. https://opensiuc.lib.siu.edu/cgi/viewcontent.cgi?article=1059\&context=gs_rp

[33] Tufts, A. (2013) Born to Be an Offender? Antisocial Personality Disorder and Its Implications on Juvenile Transfer to Adult Court in Federal Proceedings. Lewis \& Clark Law Review, 71, 333-359.

https://pdfs.semanticscholar.org/46e9/61831df5b25f2abe7fe7ee5668bb649d85d5.pdf

[34] Aggarwal, I. (2013) The Role of Antisocial Personality Disorder and Antisocial Behavior in Crime. Inquiries Journal/Student Pulse, 5, 1-2.

http://www.inquiriesjournal.com/a?id=1658 